\title{
Childhood Choroid Plexus Papilloma
}

National Cancer Institute

\section{Source}

National Cancer Institute. Childhood Choroid Plexus Papilloma. NCI Thesaurus. Code C5800.

A choroid plexus papilloma that arises in the brain during childhood. 